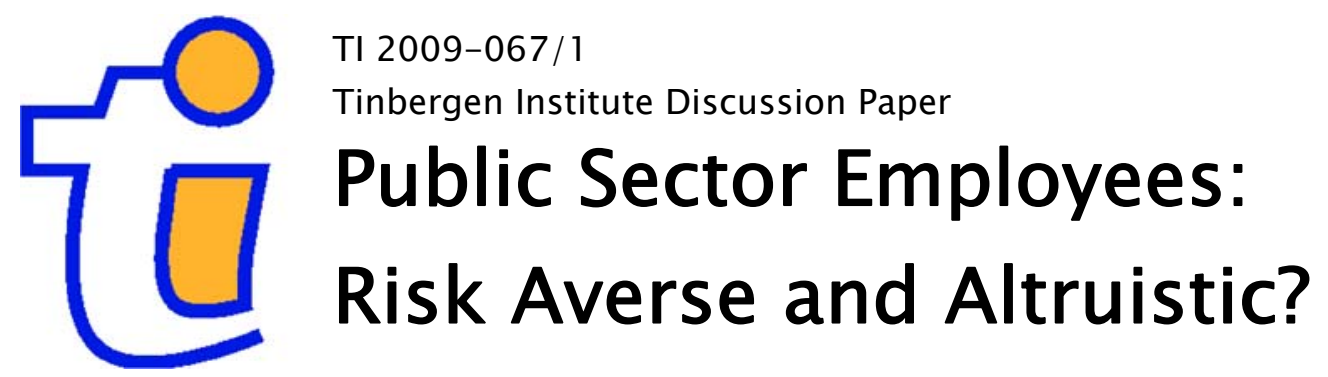

Margaretha Buurman'
Robert Durl,2

Seth Van den Bossche ${ }^{3}$

' Erasmus University Rotterdam;

2 Tinbergen Institute;

3 TNO Work and Employment. 


\section{Tinbergen Institute}

The Tinbergen Institute is the institute for economic research of the Erasmus Universiteit Rotterdam, Universiteit van Amsterdam, and Vrije Universiteit Amsterdam.

Tinbergen Institute Amsterdam

Roetersstraat 31

1018 WB Amsterdam

The Netherlands

Tel.: +31(0)205513500

Fax: $+31(0) 205513555$

Tinbergen Institute Rotterdam

Burg. Oudlaan 50

3062 PA Rotterdam

The Netherlands

Tel.: + $31(0) 104088900$

Fax: $+31(0) 104089031$

Most TI discussion papers can be downloaded at http://www.tinbergen.nl. 


\title{
Public Sector Employees: Risk Averse and Altruistic?*
}

\author{
Margaretha Buurman† Robert Dur; and Seth Van den Bossche ${ }^{\S}$
}

July 29, 2009

\begin{abstract}
We assess whether public sector employees have a stronger inclination to serve others and are more risk averse than employees in the private sector. A unique feature of our study is that we use revealed rather than stated preferences data. Respondents of a large-scale survey were offered a substantial reward and could choose between a widely redeemable gift certificate, a lottery ticket, or making a donation to a charity. Our analysis shows that public sector employees are significantly less likely to choose the risky option (lottery) and, at the start of their career, significantly more likely to choose the pro-social option (charity). However, when tenure increases, this difference in pro-social inclinations disappears and, later on, even reverses. Our results further suggest that quite a few public sector employees do not contribute to charity because they feel that they already contribute enough to society at work for too little pay.
\end{abstract}

Keywords: public service motivation, risk aversion, revealed preferences data.

JEL codes: H1, J45, M52.

*We gratefully acknowledge comments and suggestions by Josse Delfgaauw and participants to the 2009 CMPO Workshop 'Public services and worker motivation' in Bristol.

${ }^{\dagger}$ Department of Economics, Erasmus University Rotterdam. E-mail: buurman@ese.eur.nl

${ }^{\ddagger}$ Department of Economics, Erasmus University Rotterdam, Tinbergen Institute, CESifo, and IZA. E-mail: dur@ese.eur.nl

${ }^{\S} \mathrm{TNO}$ Work and Employment. E-mail: seth.vandenbossche@tno.nl 


\section{Introduction}

It is often argued that preferences and work motivations of public sector employees differ from those of private sector employees. Some of these differences stem from sectoral differences in the nature of jobs. Many jobs in the public sector involve helping people in need or contributing to society at large, rendering these jobs attractive to people who have a strong willingness to serve others or the public interest. ${ }^{1}$ Another, less honorable motivation for seeking a job in the public sector is avoidance of risk. In most countries, employers in the public sector offer higher job security and less volatile wage compensation than employers in the private sector (Clark and Postel-Vinay 2009, Bonin et al. 2007). As a result, highly risk-averse people may find it attractive to opt for a job in the public sector (Bellante and Link 1981).

This paper employs a unique dataset to assess whether public sector employees have a stronger inclination to serve others and are more risk averse than people employed in the private sector. In contrast to previous empirical studies, we explore revealed preferences rather than stated preferences. Our data come from a questionnaire held in 2000 covering more than 3000 employees in The Netherlands. Upon completing the questionnaire, each participant was offered a reward worth 25 guilders (11,34 euro; about $15 \%$ of daily disposable household income in 2000). Participants could choose between receiving a widely redeemable gift certificate, receiving a national lottery ticket, or donating the reward to a charity of their choice. We hypothesize that, as compared to private sector employees, public sector employees more likely choose to donate to charity (the safe and pro-social choice) and less likely choose the lottery ticket (the risky choice) rather than choose the gift certificate (the safe and selfish choice).

Our results lend strong support to the hypothesis that public sector employees are more risk averse than private sector employees. People holding a public sector job are much less likely to choose the lottery ticket rather than the gift certificate. This holds both before and after controlling for income, gender, age and several other observable characteristics. The difference is substantial: Our estimation results imply that the odds for a public sector

\footnotetext{
${ }^{1}$ See the large literature in public administration on 'public service motivation' (e.g. Perry and Wise 1990, Perry 1996, Rainey and Steinbauer 1999, Wright 2001) and several recent theoretical studies in economics (e.g. Dixit 2001, Besley and Gathak 2005, Francois 2007, Delfgaauw and Dur 2008). Perry et al. (2009) and Francois and Vlassopoulos (2008) provide overviews of these literatures.
} 
worker of choosing the lottery ticket rather than the gift certificate are 0.68 times the odds for a private sector worker.

We find only weak evidence for the hypothesis that public sector employees more likely choose the pro-social option of donating to charity rather than choose the selfish option of taking the gift certificate. On the contrary, our analysis reveals that, after controlling for observable individual characteristics, public sector employees are significantly less likely to donate to charity. The odds for a public sector worker of donating his reward to charity rather than taking the gift certificate are 0.74 times the odds for a private sector worker. Behind this average figure is a remarkable relation between inclinations to donate to charity and employee's tenure in a public sector organization. Employees who have just started a job in the public sector are significantly more likely than their private sector counterparts to donate to charity rather than to take the gift certificate. However, within a few years, this difference disappears and later on even reverses. Importantly, we find no tenure effects for private sector workers' inclination to donate to charity, nor does tenure affect the likelihood of choosing the risky option in either of the sectors. Moreover, the tenure effect for public sector worker's inclination to donate to charity remains intact when we allow for public-sector specific age effects.

This tenure effect is well in line with the observations made by Blau (1960: 347, 348) in his study of case workers in a public welfare agency. He finds that "the attitudes of most new case workers toward clients were strongly positive, if somewhat sentimental and idealistic (...) the new case worker was typically full of sympathy for clients' problems. But as he encountered clients who blamed him personally for not helping them enough, even though agency procedure limited him, and clients met his trusting attitude by cheating and lying, the newcomer tended to experience a 'reality shock' (...) This disillusioning experience might make a worker bitter and callous, or induce him to leave the job, and even those who did not have either of these extreme reactions tended to change their orientation to clients." "In sum, experience increased the case worker's ability to serve recipients but decreased his interest in doing so." (Blau 1960: 359). Likewise, Van Maanen (1975) reports swift declines in motivation among police recruits during their first year in a big-city department, which are partly accounted for by more pessimistic beliefs about the likelihood of receiving favorable responses from the community to 'working especially hard.' Similar findings are reported by De Cooman et al. (2009) using data from a repeated survey among Flemish 
teachers who just started their professional career. They find that, within two years time, "work values became somewhat less ideological and more self-oriented." Further, teachers "attached greater importance to extrinsic values, including rewards, security, career, and recognition, and less importance to altruistic values including social service, though these changes were relatively small." (p. 105-106)

It is important to note that our analysis gives an indication of people's marginal willingness to accept risk and to make charitable contributions; it does not reveal people's overall risk aversion or pro-social attitude. The two need not coincide. For instance, employees in the private sector may generally be more risk tolerant than public sector employees, but exhibit more risk averse behavior at the margin because in their professional life they are already exposed to more risk than public sector employees. Likewise, public sector employees may be less willing to donate their reward to charity as they already serve the public interest in their professional life on a day-today basis. Unfortunately, we lack data on how much risk people face and how much they contribute to the public interest in daily life. However, we do find some indirect evidence for the idea that public sector employees less likely donate to charity because they feel they already contribute a lot to society at work. One of the questions in the survey asked people whether they consider their salary to be sufficient for the work that they do. People responding negatively to this question less likely donate their reward to charity rather than take the gift certificate. Importantly, this effect is significantly stronger for employees in the public sector, both statistically and economically (the effect is twice as large). This suggests that public sector employees consider the contributions they make on the job as a substitute for making charitable donations. Feeling underpaid explains a large part of the average difference between pro-social inclinations in the sectors. This is partly due to the stronger effect of feeling underpaid on public sector employees' likelihood to donate. Further, a much larger fraction of employees in the public sector feel that they are underpaid (56\% in the public sector as compared to $42 \%$ in the private sector). Comparing dissatisfied employees in the public and private sector, we find no significant difference in the early stages of the career, while later on public sector employees are significantly less likely to donate. Satisfied public sector employees significantly more often choose to

\footnotetext{
${ }^{2}$ Similar patterns have been observed among volunteers, see Tschirhart et al. (2001) and references therein.
} 
donate in the early stage of their career, while later on there is no significant difference with their private sector counterparts.

Although we can only assess people's risk and pro-social attitude at the margin, we do think our results are of great relevance for recent debates about remuneration of employees in the public sector (see, e.g., Burgess and Ratto 2003, National Commission on the Public Service 2003, OECD 2005 and 2008). First, measuring tolerance for additional risk of public sector employees gives some indication of the effects of introducing or strengthening pay-for-performance for workers in the public sector. Making employees' pay more dependent of their performance usually increases the risks employees face, as their performance not only depends on their effort, but also on random events. Our results suggest that public sector employees have a stronger distaste for taking risks than their counterparts in the private sector, implying that (with the current workforce) pay-for-performance is a more costly instrument to induce effort in the public sector than in the private sector. Second, measuring pro-social inclinations at the margin gives an idea about how much society can rely on public sector employees' altruistic motivations when additional helping opportunities arise. Our results give rise to some pessimism: Many public sector employees feel that they are underpaid relative to the contributions that they make, which makes them hesitant to provide further contributions.

We proceed as follows. The next section briefly describes earlier studies on differences in preferences and motivations between public and private sector employees. Section 3 describes the data. Section 4 presents the main results and Section 5 concludes.

\section{Related literature}

A rich literature in public administration and a growing number of studies in economics have examined differences in preferences and motivations between public and private sector employees. Existing empirical studies can be divided into two groups: those that use stated preferences or motivations (e.g., by asking respondents how important job security or helping other people is to them) and those that infer preferences and motivations from stated behavior (e.g., self-reported donations to charity, self-reported purchase of insurance, stated willingness to pay for a hypothetical lottery, et cetera). Our study is the first using revealed preferences data rather than stated prefer- 
ences data; that is, we use data on what people actually do, not on what they say they do or what they claim is important to them. This has some clear and well-known advantages. In particular, stated preferences data may be vulnerable to self-stereotyping, self-serving biases, lack of attention by respondents, and strategic motives (Roszkowski and Grable 2007, Dohmen et al. 2009). For instance, it has been shown that in experiments with hypothetical payments subjects appear more generous and more risk-preferring than when real money is at stake (Camerer and Hogarth 1999).

Most studies comparing public and private sector workers have assessed in how far public sector workers have a particular willingness to serve the public interest, to help others, and to make personal sacrifices in order to do so. For instance, Rainey (1982) and Lewis and Frank (2002) find that public sector workers more often rate work attributes such as 'Useful to society' and 'Help others' as (very) important (see also Kilpatrick et al. 1964, Buchanan 1975, Crewson 1997, Houston 2000, and Steijn 2008 among others). Houston (2006) uses data on self-reported pro-social behavior, such as volunteering, donating blood, and making charitable contributions. He finds that nonprofit and public sector employees are more likely to report being a volunteer and blood donor, while no such relation is found for charitable contributions. Likewise, Brewer (2003) shows that public sector employees report higher levels of participation in nonpolitical civic affairs. Recently, Gregg et al. (2009) exploit British panel data and find that individuals who are more inclined to donate labor (as measured by stated unpaid overtime) select into the non-profit sector.

Other studies have examined whether public and private sector workers differ in risk preferences. Studies using stated preferences about job security find mixed evidence (see e.g. Rainey 1982, Crewson 1997, Houston 2000, and Lewis and Frank 2002). By contrast, Bellante and Link (1981) use answers to questions like the condition and insurance of cars owned, the use of seat belts, the extent of medical coverage, and smoking and drinking habits to construct a measure of risk aversion. They find that, thus defined, risk-averse people are more likely to be employed in the public sector than in the private sector. Likewise, Roszkowski and Grable (2009) use data on clients of financial planners who had completed a test of financial risk tolerance. They find that public sector employees score significantly lower than private sector employees, even after controlling for a rich set of observables. Similar results are obtained by Hartog et al. (2002) for The Netherlands and by Guiso and Paiella (2008) for Italy using large-scale survey data on people's willingness 
to pay for a hypothetical lottery and for a hypothetical risky security, respectively. Several recent papers in economics have added to this body of evidence using the 2004 wave of the German Socio-Economic Panel data, which contains questions on people's attitude towards risk-taking. Bonin et al. (2007) show that working in the public sector implies a significantly lower earnings risk than working in the private sector and that individuals who are less risk tolerant more likely end up working in an occupation with low earnings risk. Using the same data, Luechinger et al. (2007) and Pfeifer (2008) directly estimate the effect of self-reported risk attitude on sector of employment and report similar findings: people who are less willing to take risk are more likely to be found in the public sector.

\section{Data and empirical strategy}

We use data from the TNO Work Situation Survey (TAS), a Dutch survey developed by TNO (an independent research organization, partly funded by the Dutch government) in cooperation with the Ministry of Social Affairs and Employment. The survey was conducted in 2000 among about 8000 employees and self-employed persons in all sectors of the economy. The response rate was $53 \%$, resulting in 4334 respondents (see Smulders et al. 2001 and Bakhuys Roozenboom et al. 2007). ${ }^{3}$ The survey includes a rich set of demographic variables and data on a wide range of work-related topics, such as employment conditions, pay, hours worked, job and pay satisfaction, attitude towards work, intention to leave, job security, health-related issues, and workplace characteristics.

Our key variable of interest is the type of reward chosen by the respondents for completing the survey (see Appendix A for the exact question and possible answers). ${ }^{4}$ Respondents could choose between receiving a widely redeemable gift certificate, receiving a national lottery ticket, or donating the reward to a charity of their choice. All types of reward had the same face value: 25 guilders (11.34 euro), about $15 \%$ of daily disposable household

\footnotetext{
${ }^{3}$ See for more information in English: http://www.eurofound.europa.eu/ewco/surveys/ national/countries/netherlands2005_6_tas.htm

${ }^{4}$ The survey was repeated in 2002 and 2004 . We do not use these data in our analysis because in 2002 the data-collecting company did not report data on our key variable and in 2004 the reward for respondents was substantially lower and differed between completing the internet questionnaire (10 euros) and the written questionnaire (7,50 euros).
} 
income in 2000.

Since respondents indicated their main economic sector in the survey, but not whether their organization belongs to the public or private sector, we recoded the main economic sectors into public or private, using a data file we obtained on request from Statistics Netherlands. The sectors thus included in the public sector are education, hospitals, nursing homes, welfare work, and central and local government. Four economic sectors contain a substantial mix of private and public organizations; we omit these sectors from our analyses. ${ }^{5}$ Furthermore, we confine ourselves to employees, leaving out the self-employed, owners of firms, and (unpaid) family workers. We also restrict the sample to respondents between 20 and 64 years of age, because there are very few respondents under 20 years of age and 65 is the regular Dutch retirement age. These selections leave us with a sample of 3126 respondents.

Our empirical strategy is to examine whether an otherwise comparable respondent differs in his choice of reward depending on the sector of employment. If public sector workers are more altruistic and more risk averse at the margin, we should find that public sector workers are more likely to donate the reward to charity and less likely to choose the lottery ticket rather than to opt for the gift certificate. Since our dependent variable has three potential categorical outcomes (lottery ticket, charity, gift certificate) we analyze our data using a multinomial logistic regression model. We take gift certificate as our reference category, as this is the safe and selfish alternative. ${ }^{6}$

Obviously, the choice of the reward does not only depend on a respondent's risk preferences and pro-social attitude, but also on other characteristics such as income. People with a low income may be more likely to choose the gift certificate, as this could be exchanged for basic necessities such as food or clothing. Therefore, we control for net monthly income in the regression analyses, as well as for whether the respondent is the breadwinner of his household. Since our categorical income measure is somewhat crude,

\footnotetext{
${ }^{5}$ These four sectors are: Other type of industry (which also comprises workers in sheltered employment), other type of transport and communication (which includes public transport), other type of healthcare (among others general practitioners and midwifes) and culture, sports, and recreation.

${ }^{6} \mathrm{We}$ also ran binary logistic regression models (grouping charity and gift certificate as the safe options; grouping gift certificate and lottery as the selfish options; taking only the gift certificate as the selfish option, dropping the lottery ticket; and taking only the gift certificate as the safe option, dropping the charity). All these models produced results similar to the multinomial logistic regression model and are for brevity not reported.
} 
especially in the highest category, we also add managerial position to our analysis. This is likely to pick up some additional income effects. Moreover, we include the following demographic controls: Age, sex, region, education, marital status, and the number of children living at the home.

An important issue is whether public and private sector employees had different attitudes before they sorted into their sector of employment or changed their attitudes afterwards. To account for such tenure effects, we add employee's tenure at the organization and interact it with the employee's sector of employment. ${ }^{7}$ Finally, we check whether feelings of underpayment affect employee's choice of reward using the question "Is your salary sufficient for the work that you do?" and we also interact this variable with the employee's sector of employment.

Table 1 contains the descriptive statistics of our subsample. Some interesting differences between public and private sector employees are visible. First of all, private sector employees choose the lottery ticket (48\%) more often than public sector employees (36\%). Public sector employees on the other hand choose to donate to charity (23\%) somewhat more often than private sector employees (21\%). Further, there are substantial differences in sociodemographic variables. Public sector workers are slightly older on average than private sector employees, 44 versus 42 years old, and are far more often female, $42 \%$ versus $18 \%$. Public sector employees are (therefore) also less likely to be the breadwinner in the household than private sector employees (67\% versus $79 \%$ ). The majority of public sector employees completed higher vocational education or university studies (66\%), against only a minority of private sector employees (36\%). Nevertheless, the differences in income are not that large. There is, however, a large difference in the answers to the question "Is your salary sufficient for the work you do?". Less than half of public sector employees answers this question in the affirmative (44\%), while more than half of the private sector employees is satisfied with their salary $(58 \%)$. Finally, tenure among public sector employees in our sample is also longer than that of private sector employees, 13.8 versus 11.8 years.

\footnotetext{
${ }^{7}$ Unfortunately, we lack data on respondent's sectoral tenure.
} 


\section{Results}

Table 2 reports the results of our multinomial logistic regression analyses. ${ }^{8}$ In model 1 we take up the public sector dummy as the sole explanatory variable. Public sector employees are, as expected, significantly less likely than private sector employees to choose the lottery ticket rather than the gift certificate. However, in contrast to our expectations, public sector employees are also less likely than private sector employees to opt for a donation to charity rather than for the gift certificate. This effect, however, is not significant and relatively small. Model 1 only explains little variation in the choice of reward. Although it does fine in predicting the choice of the lottery ticket, it performs extremely poor in predicting the choice of the charity. As we noticed in the previous section, there are many more differences between public and private sector employees than just sector of employment. Therefore, we add several controls in model 2 .

Remarkably, model 2 shows results quite close to model 1: Compared to private sector employees, public sector employees are 0.74 times less likely to choose the charity rather than the gift certificate. This time, the effect is significant at the 5\%-level. Public sector employees are also significantly less likely to choose the lottery ticket over the gift certificate, as in the previous model. Our estimation results imply that the odds for a public sector worker of choosing the lottery ticket rather than the gift certificate are 0.68 times the odds for a private sector worker.

The choice for the lottery ticket is significantly related to some of the demographic variables. Women are less likely to choose the lottery ticket over the gift certificate, as are employees with a higher level of education. Couples with children living at home are more likely to choose the lottery ticket than singles. However, the larger the number of children, the less likely employees choose the lottery ticket. Finally, income and other variables affecting people's budget do not really matter. ${ }^{9}$ Income does, however, matter for donating to charity. All budget-related variables show that as people's budget increases, the odds of choosing the charity over the gift certificate

\footnotetext{
${ }^{8}$ For ease of presentation, we treated managerial position, income, and education as continuous variables in table 2 . We also ran regressions using the ordinal categories of these variables. This gave nearly the same results at the same significance levels.

${ }^{9}$ The results for the control variables are close to those of Hartog et al. (2002) and Dohmen et al. (2009), except for the effect of education, which is positive in these earlier studies.
} 
increase as well. A higher income or higher managerial position increases the odds of choosing the charity over the gift certificate significantly, as does not being the breadwinner. Furthermore, some of the demographic variables also have an effect. Couples with children living at home are less likely to choose the charity over the gift certificate than singles, although this effect is only significant at the 10\%-level. Older employees are more likely to choose the charity over the gift certificate, as are employees with a higher level of education. ${ }^{10}$ Lastly, note that the fit of model 2 is substantially better than that of the previous model. ${ }^{11}$

Model 3 examines whether and if so how public sector workers' risk and pro-social attitudes develop during their career. As we discussed in the Introduction, several earlier studies have found that altruistic motivations decline with tenure among public sector employees (Blau 1960, Van Maanen 1975, and Cooman et al. 2009). We therefore add to model 2 employee's tenure at the organization as well as tenure interacted with the employee's sector, and similarly for tenure squared to allow for nonlinear effects. ${ }^{12}$ Tenure does not affect the chances of taking the lottery ticket rather than the gift certificate in either of the sectors. Figure 1a plots the point-estimates of the combined public sector dummies against tenure. Clearly, public sector employees are significantly more risk averse than private sector employees for almost all levels of tenure and there is no clear pattern in this difference over people's tenure. However, we do find strong tenure differences for public sector employees in the odds of taking the charity rather than the gift certificate, while there is no such tenure effect for private sector employees. Figure 1b, which is again based on the estimation results of model 3, shows that at the start of their careers, public sector employees are more likely to donate to charity rather than take the gift certificate than their private sector counterparts, although this is effect is not significant. After a few years, this (insignificant)

\footnotetext{
${ }^{10}$ Houston (2006) reports similar findings for these socio-demographic variables, except for gender. He obtains a significant positive effect of being female on the odds of donating to charity, whereas we find a negative, but not significant effect.

${ }^{11}$ We included ethnic minority, firm size, and age squared as additional contols in previous regressions. However, as those variables had no significant effect, we left them out of our final regressions.

${ }^{12}$ We also ran regressions including interaction terms of age and public sector so as to rule out that any possible tenure effects are actually driven by respondent's age. The interaction effect with age was never significant, nor did it change the effects and significance of tenure. Obviously, since our data are cross-sectional, we can not completely rule out that tenure effects are intertwined with cohort effects.
} 
positive effect has disappeared and even reverses. Indeed, during the main part of their careers, public sector employees are significantly less likely to donate to charity than private sector employees.

One of the reasons for a negative effect of tenure on pro-social inclinations of public sector employees might be that their tenure-wage profile is flatter than that of private sector employees, which may give rise to growing feelings of underpayment. We control for these feelings of underpayment using the variable "Is your salary sufficient for the work that you do?" and its interaction with the public sector dummy. We are particularly interested in whether public sector employees' likelihood of donating to charity is more strongly affected by feelings of underpayment than that of private sector employees. This would support the idea that donations to charity and contributions to society at the workplace are considered as substitutes by public sector employees.

Model 4 shows no significant effect of feeling underpaid on the odds of choosing the lottery ticket over the gift certificate. The other coefficients explaining the choice of the lottery over the gift certificate are not much affected. Figure 2a plots the point-estimates of the combined public sector dummies for employees who think their salary is sufficient for the work they do. During the main part of their career public sector employees are significantly less likely to choose the lottery ticket over the gift certificate than private sector employees. This pattern is almost identical for employees who do feel underpaid, as we can see in figure $2 \mathrm{~b}$.

We find striking effects of feelings of underpayment on the odds of choosing the charity over the gift certificate. Employees who feel underpaid are significantly less likely to donate to charity, and particularly so in the public sector. The odds for a dissatisfied employee of donating his reward to charity rather than taking the gift certificate are 0.68 and 0.41 times the odds for a satisfied employee, in respectively the private and public sector. ${ }^{13}$ As is clear from table 2, this difference between private and public sector workers is also statistically significant. We thus find a clear indication that public sector employees consider donations to charity as a substitute for their job-related net contribution to society. Further, it can be seen from table 2 that among the satisfied employees, public sector employees are significantly more likely to donate than private sector employees at the start of their career. How-

\footnotetext{
${ }^{13}$ The odds for the public sector can easily be computed using the estimated coefficients in table 2 .
} 
ever, as before, within a few years this effect disappears, see figure 2c. Figure $2 \mathrm{~d}$ plots the point estimates of the public sector dummy for dissatisfied employees. Clearly, among these employees, there is no significant difference in pro-social inclinations between public and private sector employees at the start of their career. As tenure increases, public sector employees become less and less inclined to donate to charity. After about seven years, the difference becomes statistically significant. Comparing figures $1 \mathrm{~b}, 2 \mathrm{c}$, and $2 \mathrm{~d}$, it follows that controlling for feelings of underpayment hardly affect the tenure profile in public sector employee's inclination to donate to charity. Inspection of the data shows that, somewhat surprisingly, there is no clear relationship between feelings of underpayment and tenure. Hence, other factors seem to play a role here, e.g. Blau (1960)'s disillusionment effect, which we discussed in the Introduction.

\section{Conclusion}

Summarizing, we have found clear support for the hypothesis that public sector employees are more risk averse than private sector employees. However, in contrast to our expectations, we have also found that public sector employees are on average less inclined to make charitable contributions than private sector employees. This effect is partly due to the fact that many more people in the public sector feel underpaid. Moreover, we have found that feelings of underpayment have much larger repercussions for the odds of donating to charity in the public sector than in the private sector, suggesting that public sector employees consider the contributions they make on the job as a substitute for charitable donations. Our findings suggest that many public sector employees feel that they already donate a lot to society by exerting effort on the job for relatively little pay and, therefore, are less willing to make any further contributions than their private sector counterparts. Lastly, we have found a clear effect of tenure on pro-social inclinations in the public sector, which arises independently of feelings of dissatisfaction about pay. As public sector employees' tenure increases, they become less and less inclined to make charitable contributions, while there is no tenure effect for private sector employees. Such evolution of preferences for public sector employees is well in line with studies by Blau (1960), Van Maanen (1975), and De Cooman et al. (2009) documenting swift declines in altruistic motivations with tenure among public sector employees. 


\section{A Appendix}

Final question of the survey:

Below you can indicate if you would like to receive a gift certificate or a state lottery ticket (without jackpot). When you choose for one of these options we need your name and address. You can also choose a charity, in that case we donate f. 25,- (11,34 euro) for every completed questionnaire to one of the organizations below. If you choose to donate to charity you do not need to fill out a name and address.

1 Gift certificate (f 25,-)

2 Lottery ticket

Charity:

3 Amnesty International

4 Unicef

5 Ronald McDonald House Charities

6 War Child

$7 \square$ Carnation Foundation
Name:

Address :

Postal code and Place :

8 Wilhelmina Foundation

9 Hart Foundation

10 Animal protection

11 Greenpeace

THANK YOU FOR YOUR COOPERATION! 


\section{References}

[1] Bakhuys Roozeboom, Maartje, Ernest de Vroome, Peter Smulders, and Seth van den Bossche (2007), Trends in de arbeid in Nederland tussen 2000 en 2004, Hoofddorp: TNO.

[2] Bellante, Don and Albert N. Link (1981), Are Public Sector Workers More Risk Averse Than Private Sector Workers?, Industrial and Labor Relations Review, 34(3): 408-412.

[3] Blau, Peter M. (1960), Orientation toward Clients in a Public Welfare Agency, Administrative Science Quaterly, 5(3): 341-361.

[4] Bonin, Holger, Thomas Dohmen, Armin Falk, David Huffman, and Uwe Sunde (2007), Cross-sectional Earnings Risk and Occupational Sorting: The Role of Risk Attitudes, Labour Economics, 14(6): 926-937.

[5] Brewer, Gene A. (2003), Building Social Capital: Civic Attitudes and Behavior of Public Servants, Journal of Public Administration Research and Theory, 13(1): 5-26.

[6] Buchanan, Bruce (1975), Government Managers, Business Executives, and Organizational Commitment, Public Administration Review, 34(4): 339-347.

[7] Burgess, Simon and Marisa Ratto (2003), The Role of Incentives in the Public Sector: Issues and Evidence, Oxford Review of Economic Policy, 19(2): 285-300.

[8] Camerer, Colin F. and Robin M. Hogarth (1999), The Effects of Financial Incentives in Experiments: A Review and Capital-Labor-Production Framework, Journal of Risk and Uncertainty, 19(1-3): 7-42.

[9] Clark, Andrew and Fabien Postel-Vinay (2009), Job Security and Job Protection, Oxford Economic Papers, 61(2): 207-239.

[10] Crewson, Philip E. (1997), Public-Service Motivation: Building Empirical Evidence of Incidence and Effect, Journal of Public Administration Research and Theory, 7(4): 499-518. 
[11] De Cooman, Rein, Sara De Gieter, Roland Pepermans, Sabrina Hermans, Cindy Du Bois, Ralf Caers, Marc Jegers (2009), PersonOrganization Fit: Testing Socialization and Attraction-SelectionAttrition Hypotheses, Journal of Vocational Behavior, 74(1): 102-107.

[12] Delfgaauw, Josse and Robert Dur (2008), Incentives and Workers' Motivation in the Public Sector, Economic Journal, 118(525): 171-191.

[13] Dohmen, Thomas, Armin Falk, David Huffman, Uwe Sunde, Jürgen Schupp, and Gert G. Wagner (2009), Individual Risk Attitudes: Measurement, Determinants, and Behavioral Consequences, Journal of the European Economic Association, forthcoming.

[14] Francois, Patrick (2007), Making a Difference, RAND Journal of Economics, 38(3): 714-732.

[15] Francois, Patrick and Michael Vlassopoulos (2008), Pro-social Motivation and the Delivery of Social Services, CESifo Economic Studies, 54(1): $22-54$.

[16] Gregg, Paul, Paul Grout, Anita Ratcliffe, Sarah Smith and Frank Windmeijer (2008), How Important Is Pro-Social Behaviour in the Delivery of Public Services?, CMPO Working Paper Series No. 08/197.

[17] Guiso, Luigi and Monica Paiella (2008), Risk Aversion, Wealth, and Background Risk, Journal of the European Economic Association, 6(6): 1109-1150.

[18] Hartog, Joop, Ada Ferrer-i-Carbonell, and Nicole Jonker (2002), Linking Measured Risk Aversion to Individual Characteristics, Kyklos, 55(1): 326.

[19] Houston, David J. (2000), Public-Service Motivation: A Multivariate Test, Journal of Public Administration Research and Theory, 10(4): 713727 .

[20] Houston, David J. (2006), "Walking the Walk" of Public Service Motivation: Public Employees and Charitable Gifts of Time, Blood, and Money, Journal of Public Administration Research and Theory, 16(1): $67-86$. 
[21] Kilpatrick, Franklin P., Milton C. Cummings, and M. Kent Jennings (1964), The Image of the Federal Service, Washington, D.C.: Brookings Institute.

[22] Lewis, Gregory B. and Sue A. Frank (2002), Who Wants to Work for the Government?, Public Administration Review, 62(4): 395-404.

[23] Luechinger, Simon, Alois Stutzer, and Rainer Winkelmann (2007), The Happiness Gains from Sorting and Matching in the Labor Market, SOEP Working Paper no. 45.

[24] National Commission on the Public Service (2003), Urgent Business for America: Revitalizing the Federal Government for the 21st Century, Washington, DC: The Brookings Institution.

[25] OECD (2005), Performance-Related Pay Policies for Government Employees, Paris: OECD.

[26] OECD (2008), The State of the Public Service, Paris: OECD.

[27] Perry, James L. (1996), Measuring Public Service Motivation: An Assessment of Construct Reliability and Validity, Journal of Public Administration Research and Theory, 6(1): 5-22.

[28] Perry, James L. and Lois R. Wise (1990), The Motivational Basis of Public Service, Public Administration Review, 50(3): 367-373.

[29] Perry, James L., Annie Hondeghem, and Lois R. Wise (2009), Revisiting the Motivational Bases of Public Service: Twenty Years of Research and an Agenda for the Future, Mimeo, Indiana University, Bloomington.

[30] Pfeifer, Christian (2008), Risk Aversion and Sorting into Public Sector Employment, IZA Discussion Paper No. 3503.

[31] Rainey, Hal G. (1982), Reward Preferences among Public and Private Managers: In Search of the Service Ethic, American Review of Public Administration, 16(4): 288-302.

[32] Rainey, Hal. G. and Paula Steinbauer (1999), Galloping Elephants: Developing Elements of a Theory of Effective Government Organizations, Journal of Public Administration Research and Theory, 9(1): 1-32. 
[33] Roszkowski, Michael J. and John E. Grable (2007), Self-Assessments of Risk Tolerance by Women and Men, Psychological Reports, 100(3): 795-802.

[34] Roszkowski, Michael J. and John E. Grable (2009), Evidence of Lower Risk Tolerance Among Public Sector Employees in Their Personal Financial Matters, Journal of Occupational and Organizational Psychology, 82(2): 453-463.

[35] Smulders, P.G.W., F. Andries, and F.W.J. Otten (2001), Hoe denken Nederlanders over hun werk? Opzet, kwaliteit en eerste resultaten van de TNO Arbeidssituatie Survey, Hoofddorp: TNO.

[36] Steijn, Bram (2008), Person-Environment Fit and Public Service Motivation, International Public Management Journal, 11(1): 13-27.

[37] Tschirhart, Mary, Debra J. Mesch, James L. Perry, Theodore K. Miller, and Geunjoo Lee (2001), Stipended Volunteers: Their Goals, Experiences, Satisfaction, and Likelihood of Future Service, Nonprofit and Voluntary Sector Quarterly, 30(3): 422-443.

[38] Van Maanen, John (1975), Police Socialization: A Longitudinal Examination of Job Attitudes in an Urban Police Department, Administrative Science Quarterly, 20(2): 207-228.

[39] Wright, Bradley E. (2001), Public-Sector Work Motivation: A Review of the Current Literature and a Revised Conceptual Model, Journal of Public Administration Research and Theory, 11(4): 559-586. 
Table 1: Descriptive statistics

\begin{tabular}{|c|c|c|c|c|}
\hline Variable & Obs & $\begin{array}{l}\text { Public } \\
\text { Sector }\end{array}$ & $\begin{array}{l}\text { Private } \\
\text { Sector }\end{array}$ & Total \\
\hline Reward: & 3126 & & & \\
\hline Gift certificate & & $41.0 \%$ & $31.3 \%$ & $34.3 \%$ \\
\hline Lottery ticket & & $35.7 \%$ & $48.1 \%$ & $44.2 \%$ \\
\hline Charity & & $23.3 \%$ & $20.7 \%$ & $21.5 \%$ \\
\hline Sex: Male (\%) & 3122 & $57.6 \%$ & $82.4 \%$ & $74.8 \%$ \\
\hline \multicolumn{5}{|l|}{ Age: } \\
\hline Mean (years) & 3126 & 44.2 & 41.9 & 42.6 \\
\hline Standard Deviation & & (8.8) & $(9.3)$ & $(9.2)$ \\
\hline Education: & 3058 & & & \\
\hline No education attended/finished & & $0.2 \%$ & $0.6 \%$ & $0.5 \%$ \\
\hline Primary school & & $0.7 \%$ & $2.8 \%$ & $2.2 \%$ \\
\hline Lower secondary school & & $6.2 \%$ & $21.4 \%$ & $16.6 \%$ \\
\hline \multicolumn{5}{|l|}{ Intermediate secondary school or intermediate } \\
\hline vocational training & & $26.9 \%$ & $39.6 \%$ & $35.6 \%$ \\
\hline \multicolumn{4}{|l|}{ Higher secondary school or higher vocational } & $35.2 \%$ \\
\hline (Post-) University & & $15.2 \%$ & $7.5 \%$ & $9.9 \%$ \\
\hline Net monthly income: & 2997 & & & \\
\hline Less than fl. 500,- & & $0.6 \%$ & $0.6 \%$ & $0.6 \%$ \\
\hline fl. 500 ,- until fl. $1000,-$ & & $1.9 \%$ & $1.5 \%$ & $1.6 \%$ \\
\hline fl. $1000,-$ until fl. $1500,-$ & & $3.8 \%$ & $3.0 \%$ & $3.3 \%$ \\
\hline fl. $1500,-$ until fl. $2000,-$ & & $7.4 \%$ & $4.4 \%$ & $5.4 \%$ \\
\hline fl. $2000,-$ until fl. $2500,-$ & & $11.8 \%$ & $9.9 \%$ & $10.5 \%$ \\
\hline fl. 2500 ,- until fl. $3000,-$ & & $14.3 \%$ & $19.3 \%$ & $17.7 \%$ \\
\hline fl. 3000,- until fl. 3500,- & & $16.6 \%$ & $18.4 \%$ & $17.8 \%$ \\
\hline fl. $3500,-$ until fl. $4000,-$ & & $13.6 \%$ & $15.0 \%$ & $14.5 \%$ \\
\hline fl. 4000 ,- until fl. 5000,- & & $19.7 \%$ & $15.7 \%$ & $17.0 \%$ \\
\hline fl. 5000,- until fl. $6000,-$ & & $5.6 \%$ & $6.2 \%$ & $6.0 \%$ \\
\hline fl. $6000,-$ or more & & $4.7 \%$ & $5.9 \%$ & $5.5 \%$ \\
\hline Breadwinner: Yes (\%) & 3105 & $67 \%$ & $79 \%$ & $76 \%$ \\
\hline Marital Status: & 3125 & & & \\
\hline $\begin{array}{l}\text { Married/cohabitating without children living at } \\
\text { home }\end{array}$ & & $25.9 \%$ & $25.0 \%$ & $25.3 \%$ \\
\hline Married/cohabitating with children living at home & & $53.5 \%$ & $59.9 \%$ & $58.0 \%$ \\
\hline Single parent & & $6.0 \%$ & $2.2 \%$ & $3.4 \%$ \\
\hline Single & & $14.6 \%$ & $12.8 \%$ & $13.4 \%$ \\
\hline \multicolumn{5}{|l|}{ Number of children living at home } \\
\hline Mean & 3125 & 1.2 & 1.2 & 1.2 \\
\hline Standard Deviation & & 1.2 & 1.1 & 1.2 \\
\hline (Continued on the next page) & & & & \\
\hline
\end{tabular}


Table 1: Descriptive statistics (continued)

\begin{tabular}{|c|c|c|c|c|}
\hline Variable & Obs & $\begin{array}{l}\text { Public } \\
\text { Sector }\end{array}$ & $\begin{array}{l}\text { Private } \\
\text { Sector }\end{array}$ & Total \\
\hline Managerial position/employer?: & 3113 & & & \\
\hline No & & $69.8 \%$ & $62.1 \%$ & $64.5 \%$ \\
\hline 1-4 employees & & $10.3 \%$ & $16.7 \%$ & $14.7 \%$ \\
\hline 5-9 employees & & $5.5 \%$ & $9.3 \%$ & $8.2 \%$ \\
\hline 10-19 employees & & $6.2 \%$ & $5.4 \%$ & $5.7 \%$ \\
\hline 20-49 employees & & $4.8 \%$ & $4.0 \%$ & $4.2 \%$ \\
\hline 50 employees & & $3.4 \%$ & $2.5 \%$ & $2.8 \%$ \\
\hline Province: & 3126 & & & \\
\hline Groningen & & $5.0 \%$ & $3.1 \%$ & $3.7 \%$ \\
\hline Friesland & & $4.1 \%$ & $4.3 \%$ & $4.3 \%$ \\
\hline Drenthe & & $4.5 \%$ & $4.2 \%$ & $4.3 \%$ \\
\hline Overijssel & & $6.9 \%$ & $7.4 \%$ & $7.3 \%$ \\
\hline Gelderland & & $12.5 \%$ & $12.4 \%$ & $12.4 \%$ \\
\hline Utrecht & & $3.0 \%$ & $3.9 \%$ & $3.6 \%$ \\
\hline Noord Holland & & $15.2 \%$ & $16.8 \%$ & $16.3 \%$ \\
\hline Zuid Holland & & $23.6 \%$ & $23.4 \%$ & $23.4 \%$ \\
\hline Zeeland & & $3.1 \%$ & $2.4 \%$ & $2.6 \%$ \\
\hline Noord Brabant & & $12.3 \%$ & $13.3 \%$ & $13.0 \%$ \\
\hline Limburg & & $7.8 \%$ & $7.2 \%$ & $7.4 \%$ \\
\hline Flevoland & & $2.0 \%$ & $1.6 \%$ & $1.7 \%$ \\
\hline \multicolumn{5}{|l|}{ Tenure: } \\
\hline Mean (years) & 3098 & 13.8 & 11.8 & 12.4 \\
\hline Standard Deviation & & $(10.1)$ & $(10.3)$ & $(10.3)$ \\
\hline Salary sufficient for the work you do? : Yes (\%) & 2887 & $44.5 \%$ & $58.3 \%$ & $53.9 \%$ \\
\hline Total number of observations & & 966 & 2160 & 3126 \\
\hline
\end{tabular}




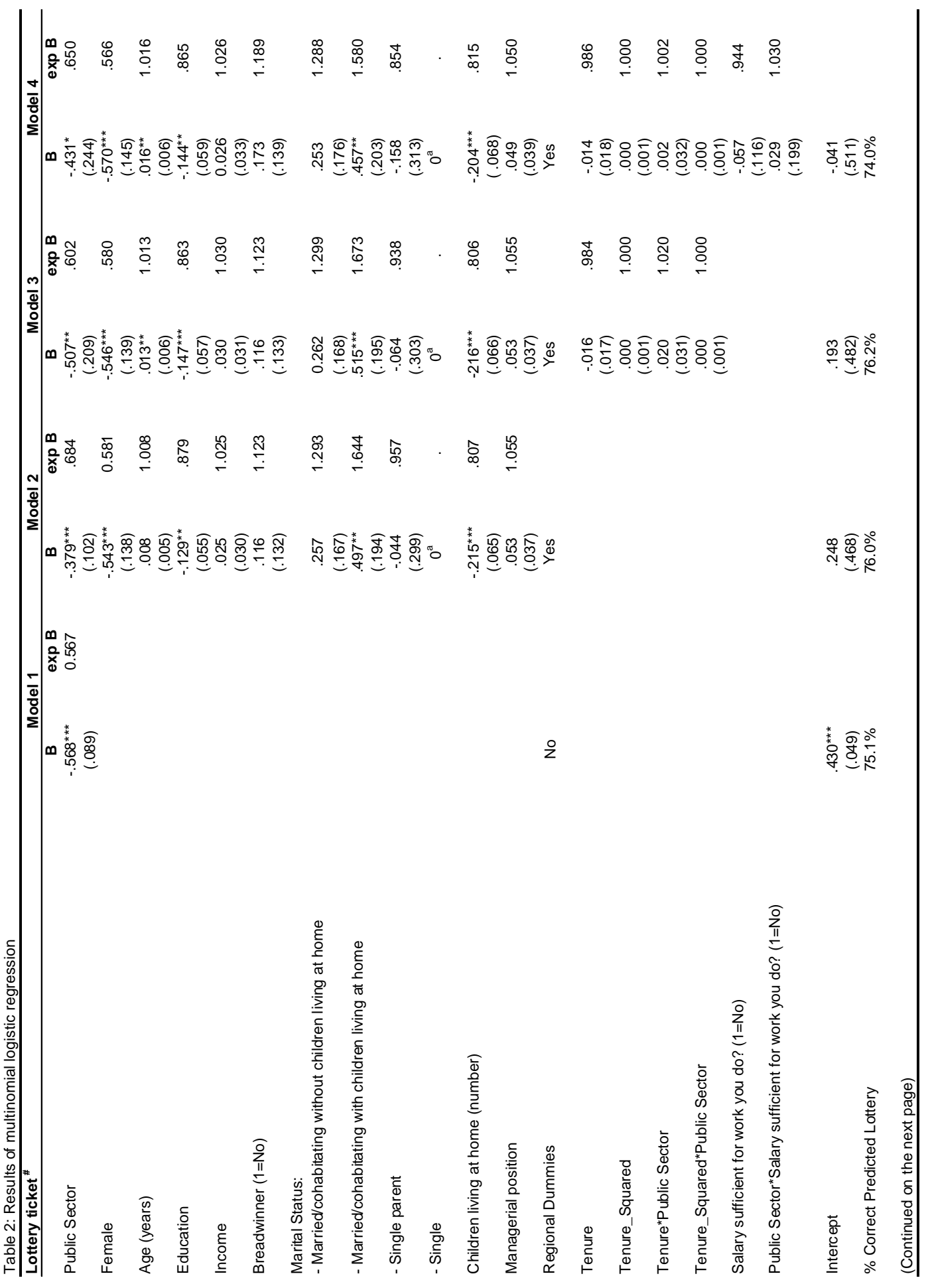




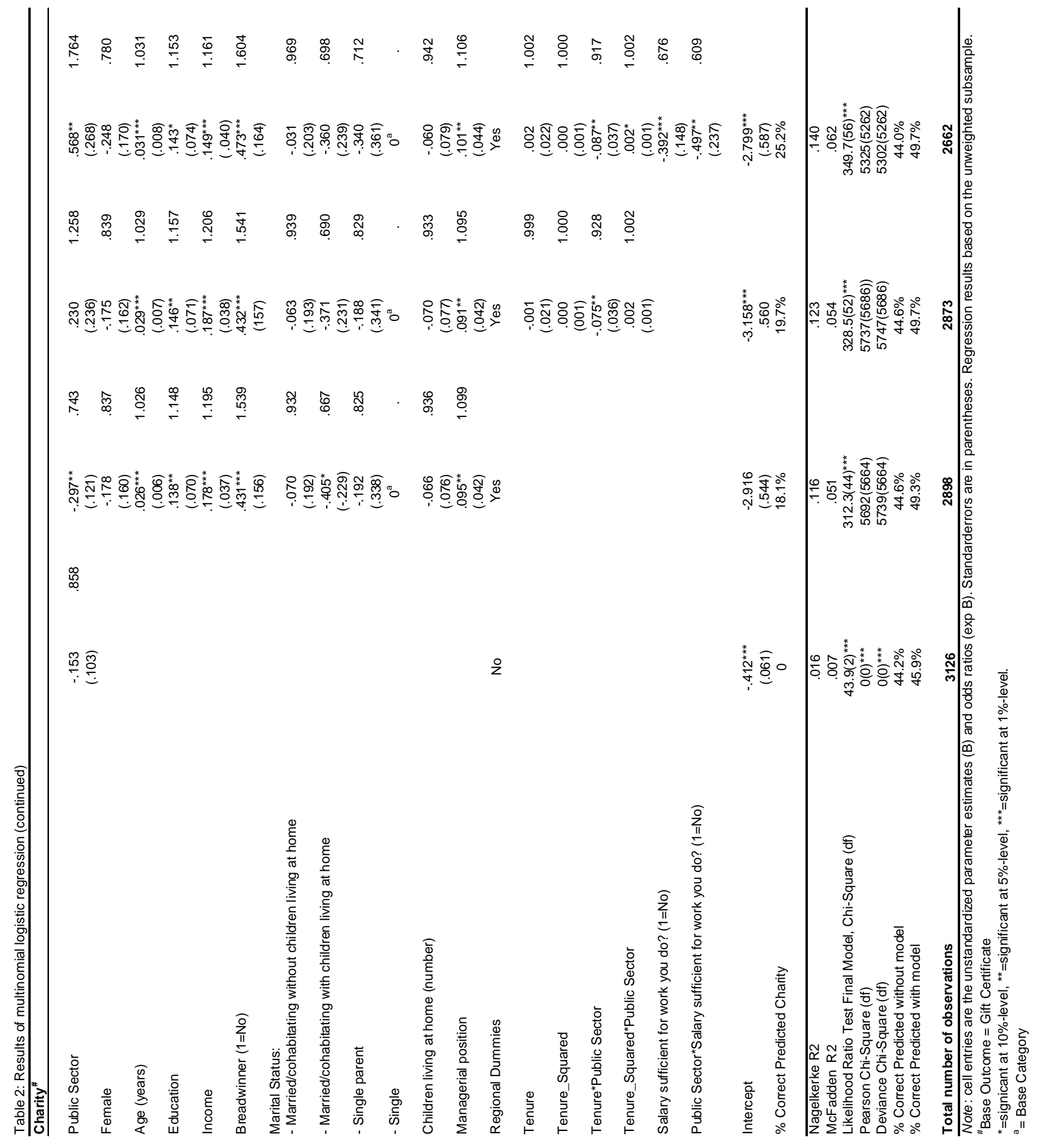



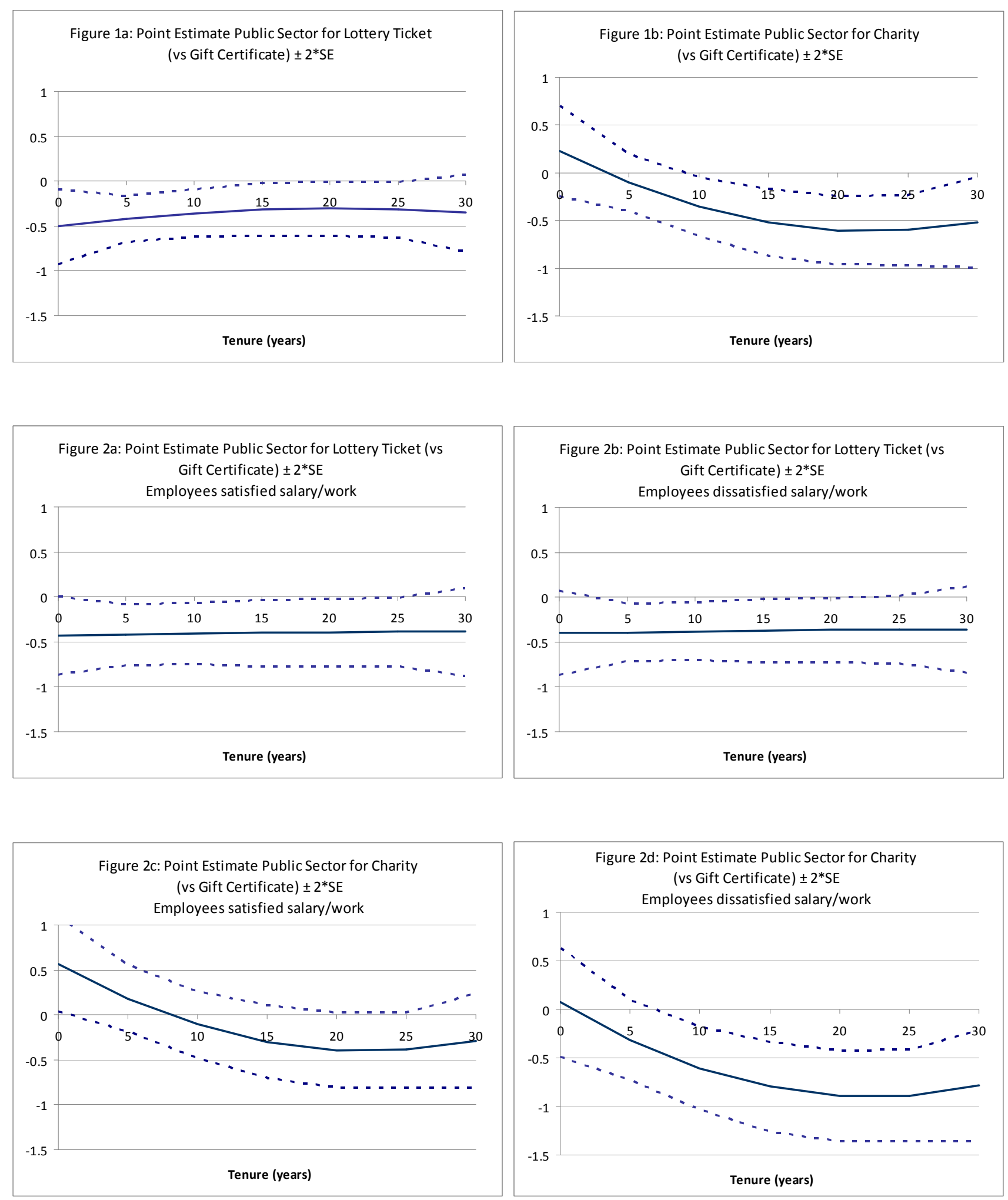